\title{
Development of a Media Literacy Skills Scale
}

\author{
Bahadir Eristi \\ Anadolu University, Turkey \\ Cahit Erdem \\ Afyon Kocatepe University, Turkey
}

\begin{abstract}
This study aims to develop a reliable and valid scale to identify the levels of media users' media literacy skills. The scale development process was carried out in nine steps as recommended in the literature. Before the scale was administered, the items were reviewed by field experts and language experts and a pilot study was carried out. Responses from 322 pre-service teachers, selected via purposeful sampling, were included in the analysis. Item discrimination was tested via item-total correlation and it indicated that none of the items were below .30. In the confirmatory factor analysis, it was found out that the scale and the theoretical model showed a fit between good and acceptable. Convergent validity, divergent validity and $27 \%$ upper-lower group means were also examined. As for the internal consistency, Cronbach's alpha value of the scale was calculated as .919 and alpha values of the factors were calculated as $.768, .833, .720$ and .838 respectively. The results revealed that Media Literacy Skills Scale, which consists of 45 items gathered under the four main factors of 'access, analyze, evaluate and communicate', is a reliable and valid measurement instrument. This up-to-date scale covers all main skills of media literacy and it consists of a sufficient number of questions to obtain rich data and ensure measurement precision. In addition, it covers new media as well as mass media and this way it fills a gap in the literature caused by the changing nature of media and technology.
\end{abstract}

Keywords: Media literacy; Scale development; Media literacy skills; New media, confirmatory factor analysis

\section{Introduction}

In specific periods of time throughout history, the concept of literacy has been defined by information and communication technologies (ICTS) commonly used in that particular era, and this fact refers to a parallelism between evolutions of literacy and ICTs. As an outgrowth of this, literacy has undergone numerous changes over time (Hsu, Ching \& Grabowski, 2009). These changes can be addressed in universal, locational and timewise dimensions. From the aspect of universal dimension, there is a consensus on the contemporary concept of literacy that has been put forth by scientific studies. Locational and timewise dimensions are, on the other hand, relative. The meaning which is attributed to literacy, literacy skills and qualities of a literate individual in a country may vary with the state that country is in with respect to its indicators of development (Ivanovic, 2014). Time wisely, the discrepancy between the meanings attached to literacy concept in the past and now is the most concrete evidence of this change (Bawden, 2001). 
The development of ICTs has not only changed the literacy concept on the levels of content and application but also has led to the appearance of new types of literacy as an outgrowth of the diversification of information and communication sources, channels and applications (Inal, 2009). Compared to the past, the current century can be regarded as a period in which new literacies of different types and qualities are defined in great numbers (Pérez Tornero, Celot \& Varis, 2007). Besides, literacy is also addressed with different concepts regarding the fundamental competencies which are defined by associating it with a specific field. Rhetoric, speaking and listening, print literacy (Hobbs \& Moore, 2013), visual literacy, information literacy, media literacy (Bawden, 2001), critical literacy (Lankshear \& McLaren, 1993), computer literacy, news literacy, digital literacy (Donna Alvermann \& Hagood, 2000), gaming literacy, social media literacy (Caperton, 2010), internet literacy and multimedia literacy (Hofstetter, 2002) are some of them.

Based on the abovementioned explanations, it can be argued that the twenty first century is a period in which ICTs have diversified; media is used so intensely; and communication process has transformed into a global action form, independent of restrictive elements (Kellner \& Share, 2007). Particularly in the last century, the internet has become a variable that has played the most significant role in the formation of this phase and it has had the potential of directly affecting literacy skills in terms of constructing information in various forms, storing and communicating and so on. By contributing to the dissemination of information independent of time and space, ICTs, particularly computers and the internet, have served a substantial role in the emergence of discussions regarding new types of literacy (Onal, 2010).

As a consequence of the change in the meaning attributed to literacy, the competencies that literate individuals need to possess are being redefined. Decoding print texts and producing new print texts are now superficial skills for an individual to be regarded as literate. The featured competencies of literate people nowadays include critically analyzing messages of different types such as texts, images, and audio files, videos in multidirectional and multidimensional information and communication channels, and creating texts in different forms. Moreover, in this new period, the problem of accessing information has been dissolved thanks to the opportunities offered by ICTs. In contrast, avoidance skills to abstain from information sources (Bawden \& Robinson, 2009) that are constructed, harmful and unreal (Potter, 2008) are regarded among the literacy skills. In addition, a literate individual today needs to possess competencies listed below (Kellner \& Share, 2005; Ayres, Langone \& Douglas, 2009; Asici, 2009; Onal, 2010):

- Recognizing and expressing facts,

- Making use of texts of different types to express one's emotions and thoughts,

- Reflecting the obtained knowledge to one's own behaviors,

- Knowing the form of texts shared in different sources and re-creating and using them,

- Possessing up-to-date knowledge and skills,

- Communicating effectively,

- Building one's capacity to be able to provide cultural and social contribution,

- Expressing oneself through using one's knowledge and skills in social and cultural field.

Regarding the change in literacy, Kress (2003) pointed out two fundamental factors stemming from social, technological and economic variables. The first of these is the move from the dominance of writing to the dominance of the image. Consequently, the second one is the transition from the dominance of the book to the dominance of the screen as a medium of communication. In the past, possessing the skills of decoding, reading and writing was regarded 
adequate for literacy because literacy was perceived as the skills of phonological awareness or resolving information and data appearing in print materials (Lundgren, 2013) since information sources were print materials to a considerable extent. Today, on the other hand, the emergence of new, different and multidimensional information and communication channels (Freire \& Macedo, 1998), accession of information to individuals through powerful images and sounds of multi-media culture (Thoman \& Jolls, 2005) have led to the extension and redefinition of competencies of the concept literacy (Silverblatt et al., 2014). The definition of literacy has been extended to include digital, electronic and visual expressions (Gentry \& McAdams, 2013).

\section{Media Literacy}

Media literacy is one of the literacy types on which academic studies have been carried out in great numbers particularly on technological literacy. There is not a consensus on a single definition of media literacy in the literature. Yet, the studies on media literacy are increasing day by day (Potter, 2010). Notwithstanding the lack of consensus, media literacy is generally defined as 'the ability to access, analyze, evaluate and communicate messages in a variety of forms' (Aufderheide, 1993). This widely acclaimed definition includes four main skills- access, analyze, evaluate and communicate- as well as using media tools and platforms effectively (Potter, 2009). In a media era of rapid technological transformations, a definition of media literacy independent of media tools at use is highly functional and significant (Livingstone, 2003).

Media literacy can be regarded as an umbrella term independent of the variables such as media tools at use, technology and so on. Besides, the unprecedented developments and increasing variety in ICTs, particularly the potentials offered by Web 2.0 , have had a significant role in the emergence of new forms of literacy such as new media literacy and social media literacy (Walsh, 2010). Furthermore, when compared to the past, the meaning attributed to media today has changed and expanded to some extent since media today is quite different from the media in the past.

According to Rivoltella (2006 as cited in Pérez Tornero, Celot \& Varis, 2007), today's media is different from the past in five ways. The new media differs from the old media as it embodies multimediality of instruments and contents, portability, high connectivity, multimediality of consumption, and high interactivity. Andersen (2002) highlights the advantages of the new media in terms of hardware and software. In addition to these advantages, he asserts that media literacy has to do with the thinking processes that are needed to use media contents and create new ones. He maintains that the new media embodies a multidirectional communication and synchronicity while the old media enables mainly one directional communication. Beside interactivity and simultaneity, synchronicity here includes miniaturization of media tools, portability, speed, access, and convergence of all these properties in a single medium.

Chen, Wu and Wang (2011) argue that the digital representation of the new media makes it programmable and computable. Besides, the new media is modular; namely, single small modules can be combined into new bigger modules to achieve different goals. They contend that these two characteristics of the new media enable the automation of operations and diversity in media creation and use. Regarding abovementioned explanations, the prominent features of new media are automation, portability, diversity, digitality, instant dissemination, modularity, multi-layeredness, hybridity and interaction (Andersen, 2002; Livingstone, 2004; Rivoltella, 2006; Jenkins et al., 2006; Anderson \& Balsomo, 2008; Chen et al., 2011). 
Since the media is not only a factor affecting the emergence of the new participatory culture but also has become a part of that culture (Jenkins et al., 2006), today's media can only be understood when socio-cultural characteristics of it are also taken into account. Socio-cultural characteristics of the media can be assessed in three aspects: (a) media messages are constructed and fictionalized and therefore reflect only one side of the reality; (b) ideological and social values are integrated into the media; and (c) the media serves for political and economic purposes among others. Besides, another socio-cultural characteristic of the new media is that each medium has its own peculiar language (Chen et al., 2013).

From the socio-cultural aspect, it can be argued that today's media offers alternative opportunities for people. The experiences in the digital revolution and the process of formation of information society reveal that people tend to adopt new technologies they encounter without questioning (Pérez Tornero \& Varis, 2010). This brings on an important problem. In mass communication, media conglomerates try to protect and expand their power and dominance by filtering information and manufacturing consent as well as controlling what people watch, listen to, think, believe, feel and perceive (Torres \& Mercado, 2010). However, the new media comes forth as an alternative to media conglomerates and makes it possible for individuals to share with other people what they have created via new media tools.

The progress brought by media tools and applications requires media literacy to be re-evaluated within the context of the twenty first century (Chen et al., 2011). Media literacy studies and research are to focus on new media tools, platforms and messages such as the internet and mobile phones besides traditional media tools (Literat, 2014). Media literacy field should focus not only on media consumption but also on the new media and the participatory culture that develops along with the new media (Jenkins et al., 2006). Therefore, the focus of media literacy has expanded to include the internet and other new media in addition to traditional print and audio-visual media (Livingstone, 2003).

Digital technology has placed media into the center of people's lives who now live in a digital balloon (Pérez Tornero \& Varris, 2010). The development of new communication technologies has transformed media consumers into media creators and the creation, sharing, and dissemination of original media messages are now defined among the characteristics of qualified media users (Literat, 2014). As people today face a bombardment of visual, audial and multimedia messages in every walk of life from televisions, newspapers and billboards to radios, sales catalogues and the internet, media literacy skills are of vital importance (Inal, 2009). Besides, schools now use media tools intensely for instruction and students' extensive use of media and educational technology requires them to possess media literacy skills. Therefore, media literacy skills are not a matter of preference but a necessity for individuals.

\section{Media Literacy Skills}

The skills and competencies that a media literate individual needs to possess are among the much-discussed issues in the literature. European Charter for Media Literacy, for instance, lists seven key competencies that media literate people should have and these include using media effectively, accessing and making informed choices about media content, understanding media content creation, analyzing media techniques and messages, using media to communicate, avoiding harmful media content and services, and using media for democratic rights and civic purposes (Bachmair \& Bazalgette, 2007). In addition to these competencies, literature highlights 
four main skills to be an effective media literate. These skills include access, analyze, evaluate and communicate (Aufderheide, 1993; Hobbs, 2001; Livingstone, 2003; Jolls, 2008; Silver, 2009; Schmidt, 2013; Silverblatt at al., 2014; Sahin, 2014). The explanations and contents of these skills are provided below.

Access involves locating and using appropriate media tools (Hobbs, 2010), reaching the targeted information via these tools, and comprehending the meanings of the contents (Jolls, 2008). For the access skill, media tools like mobile phones, ipads, televisions and computers and, more importantly, technological knowledge of a certain level are needed (Bilici, 2014). For an individual to participate in the media culture as a creator or consumer, it is prerequisite to possess the competencies within the scope of access (Schmidt, 2013). However, it should be noted that physical access to media messages or media tools does not guarantee effective use of them. With respect to the access skill which has social, cultural and technological aspects, factors such as having the permission to use media tools, knowing the use of software, peergroup norms regarding accepted actions are important (Livingstone, 2003). However, access is not limited to one-time purchase or supply as it accommodates a dynamic and social process (Livingstone, 2004). Therefore, what is important is the sustainability of use. In this sense, access can be regarded as consisting of two phases, which are physical access to media and contents of media, and the ability to use the media properly (Pérez Tornero, Celot \& Varis, 2007). Hobbs \& Moore (2013) list competencies of access skills as listening skills, comprehending content, using appropriate technology tools, asking questions, gathering information using multiple sources, implementing information to solve a problem.

Analyze may be regarded as the most prominent skill of media literacy. This is because the main goal of media literacy is to enable critical autonomy in the relation with media (Aufderheide, 1993), and the ability to analyze symbolic texts underlies media literacy (Livingstone, 2003). After accessing media contents, a set of competencies is needed to analyze those. These competencies include one's examining the structure, content, design, form and sequence of the messages with a critical perspective using artistic, literary, social, political and economic concepts (Jolls, 2008).

Analytical skill refers to dividing messages into meaningful units (Kellner, 2001). When individuals encounter media messages, they either adopt these messages superficially or they break these messages into parts and get deep into the messages by examining these parts separately (Potter, 2008). In this process, authorship, audience, form and type of the message and points of view, characters, subjects and themes, mood, setting and context in these messages are analyzed (Thoman \& Jolls, 2005; Hobbs \& Moore, 2013; Bachmair \& Bazalgette, 2007). A media literate individual with analytical skills is aware that a media message is a product of planned work and clearly sees the limit between the real world and the world virtually created by the media (Potter, 2008). Besides, a media literate individual analyzes literary strategies, possibilities and context (Lewis \& Jhally, 1998); knows how media symbols are used (Baran, 2014); knows that media uses specific techniques to create emotional influence (Bachmair \& Bazalgette, 2007); and perceives the implicit meaning as well as the explicit meaning in the messages (Volvic, 2003). Finally, a media literate individual needs to have a sufficient grasp of the background, structure and functioning of media industry to be able to comprehend and discuss what is offered through media (Taskiran, 2007).

Evaluate is a process to complete the analysis phase and a skill to make judgements about the quality or the value of a media content. Without evaluation skills, phases of access and analyze would remain inconclusive. Making a judgement is performed via comparing media content with 
a standard or a value measure (Pérez Tornero, Celot \& Varis, 2007). These values may be ethical, moral, scientific or democratic principles (Jolls, 2008). In the evaluation process, taking the potential effects or outcomes of the messages into account is also important (Hobbs, 2010). When encountered with opinions expressed in media messages, individuals either memorize and adopt them as their own opinions or compare the information elements in the message with their own standards (Potter, 2008). In this phase, one needs to evaluate the media content that they accessed and analyzed previously. In the evaluation process, one relates the messages to one's own experiences and makes judgements about the reality and quality of the messages (Thoman \& Jolls, 2005). In addition, when interpreting messages of different types and forms, a media literate individual identifies and avoids unsolicited and harmful media content (Bachmair \& Bazalgette, 2007; Silver, 2009), and evaluates the objectivity of the information in media messages with advertisement content (Sahin, 2014).

Majority of media messages are constructed with commercial, political or other purposes. Therefore, the evaluation process in which individuals question media contents with respect to objectivity and reality is of vital importance for media literacy. In the new media order, in which anyone can create one's own contents and share them with other individuals, and in which there are not sharp borders between media creators and consumers, questioning the quality of content is quite different from print texts. That is why individuals need to possess broad knowledge structures regarding social, cultural, economic, political and historic contexts to make a critical evaluation and perceive the internet not as a source of true information but as a resource whereby information is questioned, evaluated and reflected upon (Livingstone, 2003).

Communicate comprises of competencies regarding creating media messages and sharing them with other people (Schmidt, 2013). The skill of communicate is quite significant in the sense that it converts media consumers into media creators and distributors. Through this skill which enables media users to create and share their own media messages as an alternative to professionally created media contents, individuals learn the processes of content selection, editing and construction methods, techniques and technologies by doing and by this means comprehend the media kitchen way better (Bilici, 2014).

In addition to these four skills, there is a fifth skill recently discussed in the literature. This skill is called "participation" (Jolls, 2008, Thoman \& Jolls, 2005) or "act" (Hobbs, 2010) and it involves competencies regarding being an active citizen via using media tools to find a resolution to problems in family, business, social circle, or society. This skill is quite related to the 'communicate' skill and is actually a part of it. Whereas only certain information and certain points of view are available in mainstream media, new media platforms have enabled those who cannot make their voice heard to express themselves particularly with technologies that allow instant interaction. Through creating content and communicating them, individuals can actively participate in social life, support various campaigns and become active citizens who can defend their rights. In this study, the skill of communicate is regarded as a meta-concept involving the skill of participate since it involves content creation and sharing this with other people and thus participating in social life.

Measuring levels of individuals' media literacy skills is highly significant to identify users' weaknesses and provide them with relevant training. To this end, various scales have been developed (Chang et al., 2011, Ashley Maksl \& Craft, 2013; Literat, 2014). In the Turkish context, two scales, developed by Karaman \& Karatas (2009) and Korkmaz \& Yesil (2011), are used predominantly in the studies on media literacy (Som \& Kurt, 2012; Engin \& Genc, 2016; Aybek \& Demir, 2014; Cepni, Palaz \& Ablak, 2015). However, scales on media literacy need to be 
updated periodically to cope with the fast-changing nature of media and technology. In the last ten years, the development of new media tools and platforms has been pervasive and has featured particularly the "communicate" skill. A literature review on existing scales reveals that an up-to-date media literacy skills scale with enough questions to ensure rich data and measurement precision to cover all sub-skills of media literacy and to involve new media besides mass media is needed and this study aims to fill this gap.

\section{Purpose of the Study}

The main purpose of this study is to develop an up-to-date, reliable, and valid media literacy skills scale based on the media literacy skills in the literature. The reason for choosing media literacy concept in this study is to define the skills that fit to all media tools and basic skills independent of the tools and applications used as opposed to skills particular to certain media tools or platforms. It is acknowledged that defining media literacy skills regardless of media tools used is highly functional and significant in an era of rapid technological transformation. To this end, research questions in this study are as follows:

1. Is media literacy skills scale a valid measurement tool that can be used to determine the level of individuals' media literacy skills?

2. Is media literacy skills scale a reliable measurement tool that can be used to determine the level of individuals' media literacy skills?

\section{Methodology}

In this study, scale development process was carried out in nine steps as offered in the literature (DeVellis, 2003; Tavsancll, 2006; Tekindal, 2009). These steps included; (1) literature review to clearly define what is aimed to be measured and its components, (2) generating an item pool, (3) determining the appropriate format for measurement; (4) development of the draft measurement tool, (5) review of items by experts, (6) pilot study, (7) administration of the measurement tool to a development sample, (8) carrying out reliability and validity studies, (9) finalizing the measurement tool. In the following, studies done in each step are explained in detail respectively.

\section{Scale Development Process}

In the first phase, the literature was reviewed to define media literacy clearly and to generate an item pool. Based on the literature review, the characteristics that a media literate individual needs to possess were identified. After an extensive literature review (Aufderheide, 1993; Bachmair \& Bazalgette, 2007; Baran, 2014; Bilici, 2014; EAVI, 2011; Jenkins et al., 2009; Hobbs \& Moore, 2013; Kellner, 2001; Lewis \& Jhally, 1998; Volvic, 2003; Koltay, 2011; Literat, 2014; Potter, 2008; Silver, 2009; Silverblatt et al., 2014; Taskiran, 2007; Thoman \& Jolls, 2005), a list of 166 items was formed. These items were analyzed and overlapping items were combined, which reduced the item number to 113 . The items on the reduced list were grouped under four basic media literacy skills; access, analyze, evaluate and communicate as offered in the literature. Once grouped, the items were re-examined in terms of meaning, measuring the same characteristics etc. based on the dimension-wise classification and the item number was reduced to 82 . 
After item selection, the appropriate format for measurement was selected. For the measurement of levels of media literacy skills, Likert type was chosen due to its ease, high reliability and validity as well as its successful use in measuring affective variables (Tekindal, 2009). Participants chose among the options of "(1) Completely unsuitable for me" "(2) Not really suitable for me" "(3) No idea" "(4) Quite suitable for me" and "(5) Completely suitable for me" based on their competencies on a given item.

For the content validity of the scale and the appropriateness of the items for measuring media literacy skills, field experts were consulted. The experts were professors working in education and communication faculties of various universities in Turkey. The researchers created an assessment form for experts to score the items and add feedback, and they e-mailed it to experts. Depending on the feedback from 6 experts, 22 items were omitted from the draft scale and item number was reduced to 60 . Next, the draft scale was sent to five language experts who were Turkish language teachers with experience of at least five years in Turkey and necessary changes were made on the scale regarding spelling, punctuation and language use based on expert feedback. The pilot study consisted of two phases. In the first phase, 17 freshmen students at a state university took the draft scale. In the second phase, a discussion was held with students regarding the scale and the expression level of the items. The discussion was on how the students perceived the items, the items that they had difficulty in understanding, and the face validity of the draft. Based on the feedback, 13 more items were omitted and a scale consisting of 47 items were administered to development sample.

\section{Participants}

Purposeful sampling (Creswell, 2002) was adopted for participant selection. The data of the study were gathered from 322 university students. The criteria considered in determining the sample size were that sample size should be at least five times the number of items (Sencan, 2005; Tavsancil, 2006) and that a sample size of at least 300 participants is needed for factor analysis (Field, 2009). The participants were students studying at the education faculty of a state university in Turkey in 2015-2016 academic year. Participants' gender, department and grade information is given in Table 1.

Table 1. Demographics of the Participants

\begin{tabular}{lccc}
\hline $\begin{array}{l}\text { Department } \\
\text { Comp. Ed. Tech. Ed. }\end{array}$ & Male & Female & Total \\
Grade 1 & 15 & 14 & 29 \\
Science Ed. & 12 & 39 & 51 \\
Grade 1 & 7 & 28 & 35 \\
Grade 2 & & & \\
Primary Math. Ed. & 5 & 24 & 29 \\
Grade 1 & 5 & 30 & 35 \\
Grade 2 & & 31 & 37 \\
Preschool Ed. & 6 & 32 & 33 \\
Grade 1 & 1 & & \\
Grade 2 & & 20 & 40 \\
Turkish Ed. & 20 & 24 & 33 \\
Grade 1 & 9 & 242 & 322 \\
Grade 2 & 80 & & \\
Total & & & \\
\hline
\end{tabular}




\section{Procedures}

The data collection procedure was carried out in May, 2016. Permission was obtained before data collection and the students were informed about the study and forms were given to only volunteering students. The total number of students in the randomly selected departments and grades was 612. 394 students took the form and 72 students' responses were not included in the analysis as they were not completed appropriately and the analysis was performed with 322 responses.

\section{Findings}

This part includes analysis results of the construct validity and reliability. For the construct validity, confirmatory factor analysis (CFA) was performed. CFA is sounder than exploratory factor analysis because it provides more reliable data theoretically about the model and factor structure (Sencan, 2005). CFA is used when a model is constructed based on theory or previous studies and when the fit level between the model and data set is tested (Joreskog \& Sorborn, 1993). Therefore, the researcher needs to know the factor structure of the model and which variables belong to which factor and whether factors are related to each other (Thompson, 2004). The scale developed in this study is based on the hypothesis that media literacy comprises four factors grounded on the information in the literature. Therefore, CFA was considered as the best method for testing construct validity. Besides, convergent validity and discriminant validity and means of $27 \%$ upper-lower groups were also checked. For reliability, Cronbach $\alpha$ value was calculated.

\section{Item Discrimination}

Item discrimination is used to test the extent to which the items measure the construct (Buyukozturk, 2010). Before factor analysis, item discrimination of the items in the scale was tested. To this end, item-total correlation values were calculated and the observed values are given in Table 4. Item-total correlation value of an item should not be below .30 (Field, 2009). In the analysis, none of the items were below .30 and so items were appropriate for factor analysis.

\section{Mean Differences between 27\% Upper-Lower Groups}

The differences between mean scores of upper $27 \%$ and lower $27 \%$ were examined. To this end, the sum of the scores were listed ascending and groups of upper $27 \%$ and lower $27 \%$ were formed and independent sample t-test was carried out. The t-test results for $27 \%$ upper-lower group means are given in Table 2 . The t-test results showed significant differences between the means of the two groups $[\mathrm{t}(322)=28.401, \mathrm{p}<.05]$.

Table 2. t-test results for $27 \%$ upper-lower group means

\begin{tabular}{lllllll}
\hline Groups & N & X & SD & df & t & p \\
\hline Upper 27\% & 87 & 138.91 & 12.37 & 172 & 28.401 & .000 \\
Lower 27\% & 87 & 187.09 & 9.86 & 163.84 & 28.401 & .000 \\
\hline
\end{tabular}




\section{Construct Validity}

Before CFA, Kaiser-Meyer-Olkin Measure of Sample Adequacy (KMO) was checked to test whether the sample size is adequate for factor analysis. KMO values vary between 0 and 1 and it is observed as .876 in this study which is considered as "very good" in the literature (Tavsancil, 2006). This value reveals that sample size is adequate for further analysis. CFA was carried out to test whether the theoretical model offered in the scale fits the data set. The analysis program (Lisrel 8.51) suggested a modification that there would be a significant decrease in chi-square value if two of the items were omitted. Therefore, items 9 and 24 were omitted as suggested by the program. First, $t$ values of all items were above 2.56 and therefore they were significant $(p<.01)$ and are given in Table 4 . Next, the fit measures were checked. Table 3 provides acceptable fit indices (Schermelleh-Engel, Moosbrugger, \& Müller, 2003) and the related values observed in this study.

Table 3. Acceptable Values for Fit Measures and Observed Values

\begin{tabular}{|c|c|c|}
\hline Fit Measure & Acceptable values & Observed Values \\
\hline$\chi^{2} / \mathrm{sd}$ & $\begin{array}{l}0 \leq \chi 2 / \mathrm{df} \leq 2 \text { good fit } \\
2<\chi 2 / \mathrm{df} \leq 3 \text { acceptable fit }\end{array}$ & 2.00 \\
\hline GFI & $\begin{array}{l}.95 \leq \mathrm{GFI} \leq 1.00 \text { good fit } \\
.90 \leq \mathrm{GFI}<.95 \text { acceptable fit }\end{array}$ & .95 \\
\hline AGFI & $\begin{array}{l}.90 \leq \mathrm{AGFI} \leq 1.00 \text { good fit } \\
.85 \leq \mathrm{AGFI}<.90 \text { acceptable fit }\end{array}$ & .94 \\
\hline NFI & $\begin{array}{l}.95 \leq \mathrm{NFI} \leq 1.00 \text { good fit } \\
.90 \leq \mathrm{NFI}<.95 \text { acceptable fit }\end{array}$ & .94 \\
\hline NNFI & $\begin{array}{l}.97 \leq \mathrm{NFI} \leq 1.00 \text { good fit } \\
.95 \leq \mathrm{NFI}<.97 \text { acceptable fit }\end{array}$ & 1.00 \\
\hline CFI & $\begin{array}{l}.97 \leq \mathrm{CFI} \leq 1.00 \text { good fit } \\
.95 \leq \mathrm{CFI}<.97 \text { acceptable fit }\end{array}$ & 1.00 \\
\hline RMSEA & $\begin{array}{l}0 \leq \text { RMSEA } \leq .05 \text { good fit } \\
.05<\text { RMSEA } \leq .08 \text { acceptable fit }\end{array}$ & 0.056 \\
\hline SRMR & $\begin{array}{l}0 \leq \mathrm{SRMR} \leq .05 \text { good fit } \\
.05<\mathrm{SRMR} \leq .08 \text { acceptable fit }\end{array}$ & 0.059 \\
\hline PGFI & $\begin{array}{l}0 \leq \mathrm{PGFI} \leq 1 \\
\text { more parsimonious closer to } 1\end{array}$ & 0.86 \\
\hline \multicolumn{2}{|c|}{ GFI= Goodness-of-Fit Index } & AGFI= Adjusted Goodness-of-Fit Index \\
\hline \multicolumn{2}{|c|}{$\mathrm{NFI}=$ Normed Fit Index } & $\mathrm{NNFI}=$ Nonnormed Fit Index \\
\hline \multicolumn{2}{|c|}{$\mathrm{CFI}=$ Comparative Fit Index } & RMSEA = Root Mean Square Error of Approximation \\
\hline \multicolumn{2}{|c|}{ SRMR= Standardized Root Mean Square Residual } & PGFI= Parsimonious Goodness of Fit Index \\
\hline
\end{tabular}

As seen in Table 3, fit indices of the scale showed a fit between good and acceptable. First, the ratio of degree of freedom (939) to chi-square value (1882.68) indicated a good fit ( $\chi 2 / \mathrm{df}=2.004)$. In addition to the chi-square goodness of fit, other fit indices were examined and found to be good or acceptable. Goodness-of-Fit Index (GFI: .95), Adjusted Goodness-of-Fit Index (AGFI: .94), Nonnormed Fit Index (NNFI: 1.00) and Comparative Fit Index (CFI: 1.00) indicated good fit. Normed Fit Index (NFI: .94), Root Mean Square Error of Approximation (RMSEA: .056) and Standardized Root Mean Square Residual (SRMR: .059) indicated acceptable fit. Besides, Parsimonious Goodness of Fit Index (PGFI: .86) indicated a parsimonious fit. These values reveal that the model shows good and acceptable fit with the data set. For convergent validity, factor loads and construct reliability were examined. Factor loads of the items are provided in Table 4 
and they are moderate and statistically significant, providing evidence for convergence validity. For construct reliability, square of factor loads sum was divided by the sum of square of factor load and error variances sum. This value needs to be over .60. The result was .94, which refers to convergent validity. For divergent validity, correlations between factors should not be excessively high (e.g. <.90) (Kline, 2011). Correlations between factors are provided in Table 5 and the values are not high, which indicates divergent validity. Item statistics are provided in Table 4 and the diagram of confirmatory factor analysis indicating the distribution of items under each factor is provided in Figure 1. English translations of 8 sample items are provided in the Appendix.

Table 4. Item-Total Correlations and Item Statistics of Confirmatory Factor Analysis

\begin{tabular}{|c|c|c|c|c|c|c|}
\hline Item & $r$ & t value & $\begin{array}{l}\text { Error } \\
\text { Variance }\end{array}$ & $\begin{array}{l}\text { Factor } \\
\text { Load }\end{array}$ & $x$ & SD \\
\hline Item1 & $.511^{* *}$ & 20.18 & 0.67 & 0.57 & 3.87 & 0.78 \\
\hline Item2 & $.441^{* *}$ & 22.54 & 0.75 & 0.50 & 3.72 & 1.03 \\
\hline Item3 & $.433^{* *}$ & 19.22 & 0.78 & 0.46 & 3.55 & 0.91 \\
\hline Item4 & $.455^{* *}$ & 18.39 & 0.76 & 0.49 & 3.90 & 0.82 \\
\hline Item5 & $.394 * *$ & 17.29 & 0.82 & 0.42 & 3.73 & 0.90 \\
\hline Item6 & $.458 * *$ & 17.87 & 0.75 & 0.50 & 3.73 & 0.79 \\
\hline Item7 & $.506 * *$ & 22.94 & 0.68 & 0.56 & 3.32 & 0.92 \\
\hline Item8 & $.428 * *$ & 20.46 & 0.81 & 0.43 & 2.88 & 1.05 \\
\hline Item9 & $.404^{* *}$ & 18.36 & 0.83 & 0.41 & 3.23 & 0.99 \\
\hline Item10 & $.423^{* *}$ & 18.69 & 0.80 & 0.45 & 3.82 & 0.91 \\
\hline Item11 & $.529 * *$ & 24.07 & 0.67 & 0.57 & 3.75 & 0.96 \\
\hline Item12 & $.384 * *$ & 19.34 & 0.84 & 0.40 & 3.56 & 1.04 \\
\hline Item13 & $.462 * *$ & 21.68 & 0.73 & 0.52 & 3.63 & 0.92 \\
\hline Item14 & $.451^{* *}$ & 22.26 & 0.76 & 0.49 & 3.33 & 0.99 \\
\hline Item15 & $.488 * *$ & 22.02 & 0.72 & 0.53 & 3.63 & 0.90 \\
\hline Item16 & $.484^{* *}$ & 22.70 & 0.73 & 0.52 & 3.33 & 0.94 \\
\hline Item17 & $.418^{* *}$ & 18.02 & 0.81 & 0.44 & 3.55 & 0.87 \\
\hline Item18 & $.555^{* *}$ & 24.10 & 0.66 & 0.58 & 3.19 & 0.89 \\
\hline Item19 & $.500 * *$ & 21.55 & 0.68 & 0.57 & 3.88 & 0.82 \\
\hline Item20 & $.454 * *$ & 21.98 & 0.75 & 0.50 & 3.50 & 0.95 \\
\hline Item21 & $.481^{* *}$ & 24.59 & 0.73 & 0.52 & 3.47 & 1.02 \\
\hline Item 22 & $.472^{* *}$ & 19.83 & 0.74 & 0.51 & 3.85 & 0.83 \\
\hline Item23 & $.481 * *$ & 22.17 & 0.73 & 0.52 & 3.68 & 0.93 \\
\hline Item24 & $.481^{* *}$ & 22.05 & 0.70 & 0.55 & 3.98 & 0.87 \\
\hline Item25 & $.423^{* *}$ & 19.18 & 0.77 & 0.48 & 3.87 & 0.86 \\
\hline Item26 & $.483^{* *}$ & 23.36 & 0.72 & 0.53 & 3.57 & 0.95 \\
\hline Item27 & $.407 * *$ & 18.07 & 0.75 & 0.50 & 3.81 & 0.92 \\
\hline Item 28 & $.489 * *$ & 20.52 & 0.64 & 0.60 & 3.75 & 0.90 \\
\hline Item29 & $.449 * *$ & 21.96 & 0.69 & 0.56 & 3.53 & 1.05 \\
\hline Item30 & $.387^{* *}$ & 16.96 & 0.78 & 0.47 & 4.14 & 0.89 \\
\hline Item31 & $.435^{* *}$ & 18.24 & 0.73 & 0.52 & 3.66 & 0.88 \\
\hline Item32 & $.430 * *$ & 19.20 & 0.71 & 0.54 & 3.81 & 0.89 \\
\hline Item33 & $.425^{* *}$ & 19.86 & 0.75 & 0.50 & 3.58 & 1.00 \\
\hline Item34 & $491 * *$ & 25.07 & 0.70 & 0.54 & 3.84 & 1.00 \\
\hline
\end{tabular}




\begin{tabular}{lllllll}
\hline Item35 & $.552^{* *}$ & 26.80 & 0.64 & 0.60 & 3.67 & 0.98 \\
\hline Item36 & $.477^{* *}$ & 20.68 & 0.75 & 0.50 & 3.62 & 0.88 \\
\hline Item37 & $.516^{* *}$ & 25.22 & 0.65 & 0.59 & 3.89 & 0.92 \\
\hline Item38 & $.533^{* *}$ & 26.86 & 0.66 & 0.58 & 3.61 & 1.00 \\
\hline Item39 & $.434^{* *}$ & 23.09 & 0.77 & 0.48 & 3.54 & 1.03 \\
\hline Item40 & $.514^{* *}$ & 28.66 & 0.68 & 0.57 & 3.47 & 1.11 \\
\hline Item41 & $.531^{* *}$ & 25.75 & 0.65 & 0.59 & 3.74 & 0.94 \\
\hline Item42 & $.488^{* *}$ & 23.81 & 0.69 & 0.56 & 3.72 & 0.92 \\
\hline Item43 & $.394^{* *}$ & 20.44 & 0.83 & 0.42 & 2.93 & 1.04 \\
\hline Item44 & $.515^{* *}$ & 27.22 & 0.68 & 0.57 & 3.83 & 1.04 \\
\hline Item45 & .577 & 30.61 & 0.58 & 0.65 & 3.49 & 1.04 \\
\hline$* * \mathrm{p}<.01, \mathrm{n}=322$ & & & & & & \\
\hline
\end{tabular}

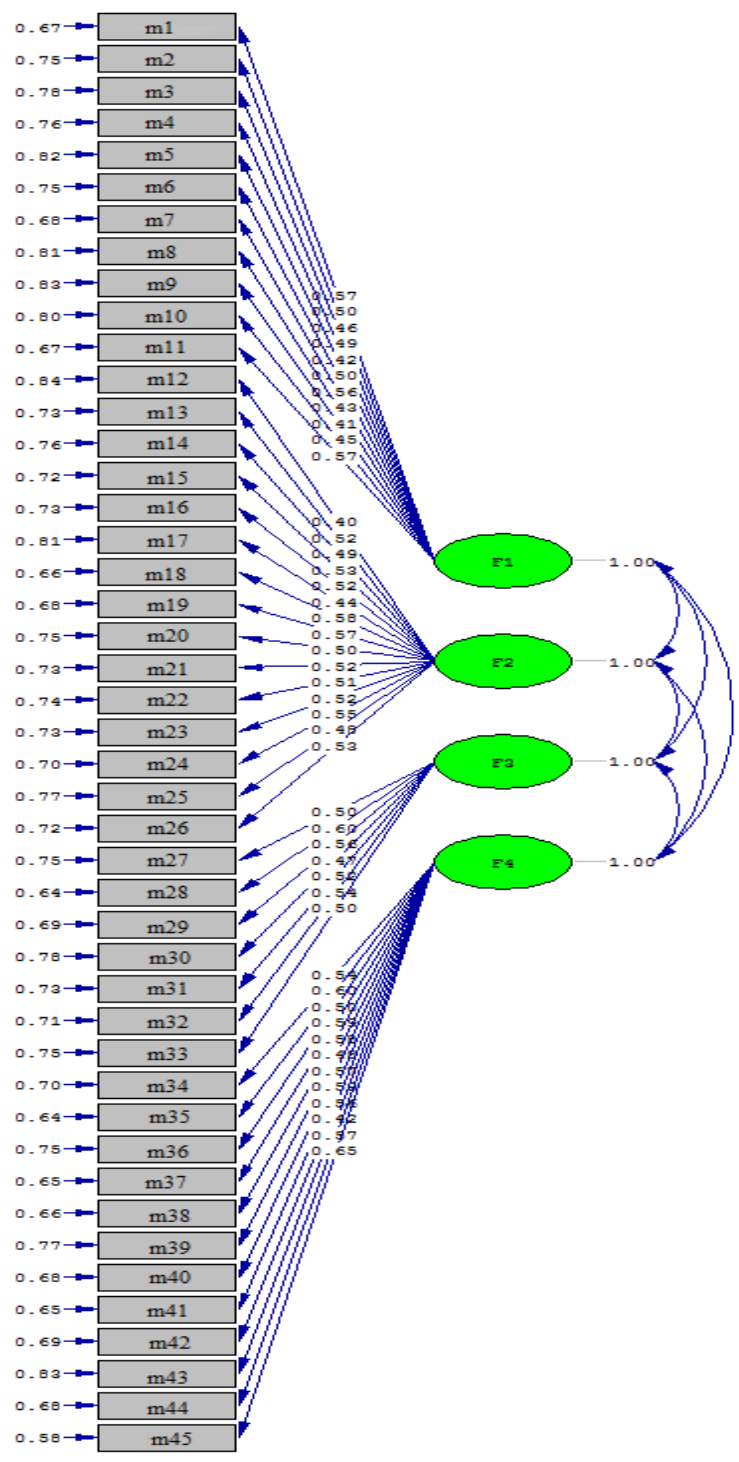

Figure 1. Confirmatory Factor Analysis Diagram of Media Literacy Skills Scale 


\section{Reliability}

Reliability of the scale was tested via the internal consistency test. Internal consistency is that items in the scale are measuring the same construct in relation to each other and reliability is mostly identified by Cronbach alpha value (Field, 2009). Internal consistency calculations revealed that Cronbach Alpha value of the scale is $(\alpha=.919)$. The alpha values for the total of the scale and for the factors are given in Table 5.

Table 5. Reliability Test Results and Correlations between Factors

\begin{tabular}{llllll}
\hline \multirow{2}{*}{ Factors } & Alpha Value & \multicolumn{4}{c}{ Correlations btw. Factors } \\
\cline { 3 - 6 } & & $\mathbf{1}$ & $\mathbf{2}$ & $\mathbf{3}$ & $\mathbf{4}$ \\
\hline Access & .768 & 1.0 & .57 & .43 & .62 \\
\hline Analyze & .833 & & 1.0 & .54 & .52 \\
\hline Evaluate & .720 & & & 1.0 & .46 \\
\hline Communicate & .838 & & & & 1.0 \\
\hline Total & .919 & & & & \\
\hline
\end{tabular}

According to the criteria regarding the appropriateness of alpha coefficient, values between .70 and .90 refer to a high level of reliability and values over .90 refer to very high level of reliability (Ozdamar, 2011). Field (2009) accepts alpha values of .7 and .8 as a reliable measure. These criteria indicate that the scale developed in this study is an instrument with a very high reliability.

\section{Results and Conclusion}

This study proposes an up-to-date media literacy skills scale. The scale was tested in terms of validity and reliability. Scale development process followed nine steps as explained in detail in the methodology section. After the literature review, an item pool was generated and items were grouped under four factors, access, analyze, evaluate and communicate. After the examination of items in terms of overlap, meaning, and measuring the same characteristics, a list of 82 characteristics was formed. 22 items were omitted after the expert opinion phase carried out for content validity and 13 items were later omitted after the pilot study. Eventually, a scale form of 47 items was administered to development sample selected through purposeful sampling. Responses from 322 participants were included in the validity and reliability analyses. First step in the analysis process was to examine item discrimination indices of the items and it indicated that item-total correlation values of all items were above .30. Mean differences between $27 \%$ upper-lower groups were found statistically significant. CFA was carried out to reveal the construct validity of the scale. The analysis revealed that the model showed good and acceptable fit with the data set after omitting two items from the scale.

Media literacy skills are classified differently by various researchers. Potter (2008) classifies media literacy skills as analysis, evaluation, grouping, induction, deduction, synthesis and abstraction. Hobbs \& Moore (2013) suggests that media literacy skills are access, analysis, construction, reflection and act. These skills or factors can be diversified; however, the widelyaccepted definition includes skills of access, analyze, evaluate and communicate. These basic skills are highly comprehensive of other skills and fit to all media tools, which makes them functional. The proposed scale consists of these factors. In the scale, access includes 11 items, analyze includes 15 items, evaluate includes 7 items and communicate includes 12 items. In 
addition, the scale was tested for convergent and divergent validity. Reliability analysis revealed that internal consistency coefficient of the scale is $(\alpha=.919)$, an indication of very high level of reliability.

Although there are various scales in the literature (Chang et al., 2011, Ashley Maksl \& Craft, 2013; Literat, 2014), there are two scales in Turkish used in media literacy studies. The former is "Media Literacy Level Determination Scale" developed by Karaman \& Karatas (2009) and the latter is "Scale of Media and Television Literacy Levels" developed by Korkmaz \& Yesil (2011). "Media Literacy Level Determination Scale" developed by Karaman \& Karatas in 2009 is a Likert type scale with 17 items gathered under 3 factors. The factors include "being knowledgeable" ( 7 items), "analyzing and reacting" ( 6 items) and "judging, being aware of the implicit messages" (4 items). "Scale of Media and Television Literacy Levels" developed by Korkmaz \& Yesil in 2011 is a Likert type scale with 18 items gathered under two factors. The factors are "literacy" (13 items) and "addiction" (5 items).

The fast-changing nature of media and technology brings about some limitations to the existing scales since the media tools people use in daily life or the ones used by students in schools change rapidly. For instance, the former scale was developed nearly ten years ago when smart phones were not as common. Another issue with the existing scales is that they do not yield rich information with respect to sub-skills of media literacy. First, the number of questions are not sufficient to provide detailed data regarding levels of media literacy sub-skills. Rather than 17 questions, 45 questions would provide more insight about their levels of media literacy skills and more measurement precision as well. Second, sub-skills of media literacy are not fully reflected in the factors of these scales. Particularly the sub-skill of "communicate" is not represented. Third, the questions in these scales are mostly about mass communication tools. Particularly the latter scale mostly consists of questions on television. However, in this new era, questions on new media should be predominant as people are now living in a digital world and they are fully engaged in new media. Thus, this scale aimed at meeting these limitations by comprehending all main skills of literacy; asking 45 questions to obtain rich data and ensure measurement precision and covering new media besides mass media and filling a gap in the literature.

In this study, a scale with 45 items under 4 factors aiming to determine the levels of media users' media literacy skills has been developed. Validity and reliability analyses revealed that the scale is a valid and reliable data collection instrument. This scale is significant because (a) the factors of the scale are based on the basic skills highlighted in the literature; (b) there is a sufficient number of questions to obtain rich data regarding the levels of individuals' media literacy skills; (c) analysis results indicate a good fit; and (d) the items of the scale mostly address new media tools and platforms besides mass media. With this scale, levels of media users' media literacy skills and their strengths and weaknesses can be identified. These data can be used as indicators of a potential training and as a needs assessment study for developing curriculum on media literacy. Particularly, determining students' levels of media literacy skills helps instructors identify the issues they need to focus while using media tools as part of educational technology. Additionally, determining prospective teachers' levels of media literacy skills and training them based on these data would be helpful as they will be teaching students in the new technology environment. This scale was validated with prospective teachers at a state university. Further research may address participants of different ages and backgrounds such as high school students, university students at different departments, teachers or other individuals and validity and reliability values and factor structure of the scale can be tested. 


\section{References}

Alvermann, D. E. \& Hagood, M. C. (2000). Critical media literacy: Research, theory, and practice in "new times". The Journal of Educational Research, 93(3), 193-205.

Andersen, N. (2002). New media and new media literacy: The horizon has become the landscape-new media are here. Report produced by cable in the classroom (pp.30-35). Retrieved on 20 January 2016 from http://www.medialit.org/reading-room/new-mediaand-new-media-literacy.

Anderson, S., \& Balsamo, A. (2008). A pedagogy for original Synners. In T. McPherson (Ed.), Digital youth, innovation, and the unexpected (pp. 241-259). Cambridge: The MIT Press.

Ashley, S., Maksl, A. \& Craft, S. (2013). Developing a news media literacy scale. Journalism \& Mass Communication Educator, 3(1), 1-15.

Asici, M. (2009). Kisisel ve sosyal bir deger olarak okuryazarlik [Literacy as a personal and social value]. Degerler Egitimi Dergisi, 7(17), 9-26.

Aufderheide, P. (1993). Media Literacy: A report of the national leadership conference on media literacy. Washington, DC: Aspen Institute.

Aybek, B. \& Demir, R. (2014). The analysis of the levels of media and television literacy of high school students in terms of different variables. Cukurova University Faculty of Education Journal, 43(1), 46-62.

Ayres, K. M., Langone, J. \& Douglas, K. (2009). Technology, UDL \& literacy activities for people with developmental delays. In L. T. W. Hin \& R. Subramaniam (Eds.), Handbook of research on new media literacy at the $K-12$ level: issues and challenges. New York: IGIGlobal.

Bachmair, B. \& Bazalgette, C. (2007). The European charter for media literacy: meaning and potential. Research in Comparative and International Education, 2(1), 80-87.

Baran, S. (2014). Introduction to mass communication: Media literacy and culture. New York: McGraw Hill.

Bawden, D. (2001). Information and digital literacies: A review of concepts. Journal of Documentation, 57(2), 218-259.

Bawden, D. \& Robinson, L. (2009). The dark side of information: overload, anxiety and other paradoxes and pathologies. Journal of Information Science, 35(2), 180-191.

Bilici, i. E. (2014). Medya okuryazarligi ve egitimi [Media literacy and its education]. Ankara: Nobel.

Buyukozturk, S. (2010). Sosyal bilimler için veri analizi el kitabı [Data analysis handbook for social sciences]. Ankara: Pegem Akademi.

Caperton, I. H. (2010). Toward a Theory of Game-Media Literacy: Playing and Building as Reading and Writing. International Journal of Gaming and Computer-Mediated Simulations, 2(1), 1-16.

Chang, C., Liu, E. Z., Lee, C., Chen, N., Hu, D. \& Lin, C. (2011). Developing and validating a media literacy self-evaluation scale (MLSS) for elementary school students. The Turkish Online Journal of Educational Technology, 10(2), 63-71.

Chen, D. T., Wu, J., \& Wang, Y.-M. (2011). Unpacking new media literacy. Journal on Systemics, Cybernetics and Informatics, 9(2), 84-88. 
Creswell, J. W. (2002). Educational research: Planning, conducting, and evaluating quantitative and qualitative research. Upper Saddle River, NJ: Pearson Education.

Cepni, O., Palaz, T. \& Ablak, S. (2015). Examining prospective social sciences teachers' level of media and television literacy according to different variables. International periodical for the languages, literature and history of Turkish or Turkic, 10(11), 431-446.

DeVellis, R. F. (2003). Scale development: Theory and applications. London: Sage.

Engin, G. \& Genc, S. Z. (2015). Examination on media literacy behaviours of teacher candidates: Ege University sample. The International Journal of Research in Teacher Education, 6(2), 1-10.

Gentry, J. \& McAdams, L. (2013). Digital story expressions: blending best practices in literacy and technology with middle school students. In American Association of Computing in Education: Paper IP 37529 (4253-4257). Chesapeake, VA: Proceedings of Society for Information Technology \& Teacher Education International Conference 2013. Retrieved on 7 January 2016 from www.editlib.org/p/48794

Field, A. P. (2009). Discovering statistics using SPSS. London: Sage.

Freire, P. \& Macedo, D. (1998). Literacy: Reading the word and the world. (S. Ayhan, Trans.). Ankara: Imge Kitabevi. (Original work published in 1987).

Hobbs, R. (2001). The great media literacy debates in 2001. Community Media Review, 21, 1723.

Hobbs, R. (2010). Digital and media literacy: A plan of action. Washington, DC: The Aspen Institute.

Hobbs, R. \& Moore D. C. (2013). Discovering media literacy: teaching digital media and popular culture in elementary schools. Thousand Oaks, CA: Corwin.

Hofstetter, F.T. (2002). Internet literacy (3rd Ed). New York: McGraw Hill.

Hsu, Y., Ching, Y. \& Grabowski, B. (2009). Web 2.0 technologies as cognitive tools of the new media age. In L. T. W. Hin \& R. Subramaniam (Eds.), Handbook of research on new media literacy at the K-12 level: issues and challenges. New York: IGI- Global.

Ivanovic, M. (2014). Development of media literacy - An important aspect of modern education. Procedia - Social and Behavioral Sciences, 149(5), 438-442.

Inal, K. (2009). Medya okuryazarligi el kitabı [Media literacy handbook]. Ankara: Utopya.

Jenkins, H., Purushotma, R., Clinton, K., Weigel, M., \& Robison, A. J. (2006). Confronting the challenges of participatory culture: Media education for the 21th century. The MIT Press. Retrieved on 15 January 2016 from https://mitpress.mit.edu/sites/default/files/titles/ free_download/9780262513623_Confronting_the_Challenges.pdf

Jolls, T. (2008). Literacy for the 21st century: an overview \& orientation guide to media literacy education. Center for Media Literacy. Retrieved on 2 January 2016 from http://medialit. org/medialitkit.html

Joreskog, K. G. \& Sorbom, D. (1993). Lisrel 8: Structural equation modeling with the simplis command language. Lincolnwood: Scientific Software International.

Karaman, K. \& Karatas, A. (2009). Ogretmen adaylarinin medya okuryazarlik duzeyleri [Media literacy levels of teacher candidates]. Ilkogretim Online, 8(3), 798-808. 
Kellner, D. (2001). New technologies/new literacies: reconstructing education for the new millennium. International Journal of Technology and Design Education, 11, 67-81.

Kellner, D. \& Share, J. (2005). Toward critical media literacy: core concepts, debates, organizations and policy. Discourse: studies in the cultural politics of education, 26(3), 369-386.

Kellner, D. \& Share, J. (2007). Critical media literacy, democracy and the reconstruction of education. In D. Macedo \& S. R. Steinberg (Eds.), Media Literacy: A reader (pp.3-23) New York: Peter Lang Publishing.

Kline, R. B. (2011). Principles and practice of structural equation modelling. New York: The Guilford Press.

Koltay, T. (2011). The media and the literacies: Media literacy, information literacy, digital literacy. Media, Culture \& Society, 33(2), 211-221.

Korkmaz, O. \& Yesil, R. (2011). Medya ve televizyon okuryazarlik duzeyleri olçegi gecerlik ve guvenirlik calismasi [Study of validity and reliability scale of media and television literacy levels]. Uluslararasi Insan Bilimleri Dergisi, 8(2), 110-126.

Kress, G. (2003). Literacy in the new media age. London: Routledge.

Lankshear, C. \& McClaren, P. (1993). Critical literacy: radical and postmodernist perspectives. Albany, NY: SUNY Press.

Lewis, J. \& Jhally, S. (1998). The struggle over media literacy. Journal of Communication, 48(1), 109-120.

Lievrouw, L. \& Livingstone, S. (2006) Introduction to the updated student edition. In L. Lievrouw, \& S. Livingstone (Eds.), Handbook of new media: Social shaping and social consequences (pp.1-14). London: Sage

Literat, I. (2014). Measuring new media literacies: Towards the development of a comprehensive assessment tool. Journal of Media Literacy Education, 6(1), 15-27.

Livingstone, S. (2003). The changing nature and uses of media literacy. MEDIA@LSE Electronic Working Papers. 4.

Livingstone, S. (2004). Media literacy and the challenge of new information and communication Technologies. The Communication Review, 7(1), 3-14.

Lundgren, B. (2013). Exploring critical literacy in Swedish education- introductory notes. Education Inquiry, 4(2), 215-223.

Onal, i. (2010). Tarihsel degisim sürecinde yasam boyu ögrenme ve okuryazarlik: Türkiye deneyimi [Lifelong learning and literacy in process of historical change: A Turkish experience]. Bilgi Dunyasi, 11(1), 101-121.

Ozdamar, K. (2011). Paket programlar ile istatistiksel veri analizi [Statistical data analysis with package programs]. Eskisehir: Kaan Kitabevi.

Pérez Tornero, J. M., Celot P. \& Varis T. (2007). Current trends and approaches to media literacy in Europe. Brussels: European Commission. Retrieved on 5 January 2016 from http://ec.europa.eu/assets/eac/culture/library/studies/literacy-trends-report_en.pdf

Pérez Tornero, J. M. \& Varis, T. (2010). Media literacy and new humanism. Moscow: UNESCO Institute for Information Technologies in Education. 
Potter, W. J. (2008). Media Literacy. Thousand Oaks, CA: Sage.

Potter, W. J. (2009). Media literacy. In W. F. Eadie (Ed.), 21st century communication, a reference (pp. 558-567). Thousand Oaks, CA: Sage.

Potter, W. J. (2010). The state of media literacy. Journal of Broadcasting \& Electronic Media, 55(4), 675-696.

Schermelleh-Engel, K., Moosbrugger, H., \& Müller, H. (2003). Evaluating the fit of structural equation models: Tests of significance and descriptive goodness-of-fit measures. Methods of Psychological Research-Online, 8, 23-74.

Schmidt, H. C. (2013). Media literacy education from kindergarten to college: A comparison of how media literacy is addressed across the educational system. Journal of Media Literacy Education, 5(1), 295-309.

Silver, A. (2009). A European approach to media literacy: moving toward an inclusive knowledge society. In D. Frau-Meigs \& J. Torrent (Eds.), Mapping media education policies in the world: Visions, programmes and challenges (pp. 11-13). New York: UNAlliance of Civilizations.

Silverblatt, A., Smith, A., Miller, D., Smith, J. \& Brown, N. (2014). Media literacy: Keys to interpreting media messages. Santa Barbara: Praeger.

Som, S. \& Kurt, A. A. (2012). Media literacy levels of students attending the department of computer education and instructional technologies. Anadolu Journal of Educational Sciences International, 2(1), 104-119.

Sahin, A. (2014). Elestirel medya okuryazarligi [Critical media literacy]. Ankara: Ani.

Sencan, H. (2005). Sosyal ve davranissal olcumlerde guvenirlik ve gecerlilik [Reliability and validity in social and behavioral measurements]. Ankara: Seckin.

Tekindal, S. (2009). Duyussal ozelliklerin olculmesi icin arac olusturma [Developing instruments for measuring affective characteristics]. Ankara: Pegem Akademi.

Taskiran, N. O. (2007). Medya okuryazarligina giris [Introduction to media literacy]. Istanbul: Beta.

Tavsancil, E. (2006). Tutumların olculmesi ve SPSS ile veri analizi [Measuring attitudes and data analysis with SPSS]. Ankara: Nobel.

Thoman, E. \& Jolls, T. (2005). Literacy for the 21st century: An overview \& orientation guide to media literacy education. CML Media Lit Kit. Retrieved on 5 January 2016 from http://www.medialit.org/sites/default/files/mlk/01_MLKorientation.pdf

Thompson, B. (2004). Exploratory and confirmatory factor analysis: understanding concepts and applications. Washington DC: American Psychological Association.

Torres, M. \& Mercado, M. (2006). The need for critical media literacy in teacher education core curricula. Educational Studies, 39(3), 260-282.

Volvic, Z. (2003). Who wants to be a media literate? Locating media research methods and applying them to the media literacy concept. Croatian Journal for Journalism and the Media, 9(2), 35-66

Walsh, M. (2010). Multimodal literacy: What does it mean for classroom practice? Australian Journal of Language and Literacy. 33(3), 211-239. 


\section{Appendix: Sample Items}

\section{Factor: Access}

I can effectively use various media tools to access the information, audio, image or other data that I need.

In order to access the information or data I need, I can functionally use different search engines and databases.

\section{Factor: Analyze}

I question the media contents that I examine with respect to the purposes they were constructed and shared for.

I question whether there is an implicit meaning and purpose or not in the messages communicated via media tools besides the explicit meaning and purposes that are perceived immediately by readers.

\section{Factor: Evaluate}

I can identify vicious and harmful media contents and I can protect myself from this kind of contents.

I can evaluate media contents or messages in media in terms of ethical principles and make a judgement about them.

\section{Factor: Communicate}

I can evaluate the possible consequences in case I share messages that contain unreal and purposeful information and images and that belong to other people and require permission to share.

Using media tools and platforms, I can arrange activities such as digital campaigns, discussion forums and blogs in order to find a solution to various problems or generate social sensitivity for a particular issue.

Correspondence: Bahadir Eristi, Associate Professor, Department of Educational Sciences, Faculty of Education, Anadolu University, Yunus Emre Campus, Eskisehir, Turkey. 